\title{
The Virus Is Organic, the Pandemic Is Political
}

\author{
Héctor Zamitiz Gamboa \\ Universidad Nacional Autónoma de México
}

This article aims to describe several contradictions that the coronavirus crisis has displayed affecting health, economy and emotional behaviour, caused by the pandemic and analyze how these problems have affected politics. Inevitably, these contradictions "politicize" public space, because politics is at the center of the fight and criticism for power and public decision-making. Politics is also a source of cohesion facing conflicts, although it has little capacity to solve them, due to economic supremacy in peoples' lives and their life project personalization, since crises undress societies and reveal the contradictions within the economic model and the nature of social inequality.

Last but not least, the article underlines some political effects caused by Covid-19 pandemic around the world, it puts forward, as well, and summarizes Mexico's difficulties.

Keywords: pandemic and politics, Covid-19 and political leadership, government and health eventuality, pandemic in Mexico

\section{INTRODUCTION}

During the first six months of 2020, much was written about the global phenomenon of the coronavirus pandemic or Covid-19, as the World Health Organization (WHO) called it in February of the same year, but in the face of the emerging global health problem, it would be an unfortunate omission not to write some more reflections, with the purpose of understanding the phenomenon's complexity and its cruel pedagogy (of "death"), because mankind must learn, as considered by the Portuguese sociologist Boaventura de Souza Santos. ${ }^{1}$

First of all, it is very important to highlight some differences in the spread of the coronavirus between countries in the East and in the West. ${ }^{2}$ For example, if we compare Italy, Germany and the United States with China, South Korea and Singapore: What is this difference? Why, if the pandemic started earlier in Asia, has it done more damage in the West, which arrived later and whose countries had more time to be prepared? How did the East contain the coronavirus better than the West?

The possible answer is that there are historical, cultural, experiential and technological factors. In the East, there is a greater obedience to the authorities, greater trust in the State that overcomes the left-right ideological axis, the experience of lockdown during the SARS epidemic, better health and research systems prepared for contingencies, the prohibition of non-essential activities, countries such as South Korea that have extended contagion tests, the use of technologies and Big Data in China, traffic light systems using QR codes with which governments exchange data to identify people. In the West, trust in the authorities is lower and people are more reluctant to obey the laws"; at first it was thought that the epidemic was "an 
Asian issue", that "it would not affect us", with health systems with cuts or dismantling; a non-favorable cultural factor to the very use of masks, with less obedience to lockdown (and perhaps less risk perception), where it is thought that Google or Facebook, have an intrusion in personal life and which should not be trusted. ${ }^{4}$

The purpose of this article is to outline some of the contradictions that the coronavirus crisis has shown us that have impacted the health, economic and emotional behavior of people, caused by the pandemic, and to highlight how these issues have had repercussions on politics, since society puts the assertiveness of its governments at stake at all times.

Contradictions unavoidably "politicize" the public space, often in a negative way, since politics is the center of the struggle and criticism for power; certainly politics is also a source of cohesion in the face of conflicts, although it has limited capacity to solve them, given the preeminence of the economy in people's lives and the individuation of their life projects, since crises unmask societies and reveal the contradictions of their economic model and the nature of social inequalities.

One of these paradoxes, perhaps the most significant, has been the criticism of governments -both by citizens and by different economic agents- when the former call on people not to leave their homes and to remain in lockdown in order to avoid contagion, leaving the economic implications in second place. This turned into a reverse criticism when governments gradually decided to open up and to end lockdown themselves, or else chose to ignore the measures established by health authorities and follow their own strategies, sometimes backed by science and sometimes only by political pragmatism. ${ }^{5}$ Although we are particularly interested in the political effects of the pandemic in the world, we highlight the most important issues of the problem in the Mexican case.

\section{Virus Mutation: A Scientific Challenge}

The official chronology of the Covid-19 pandemic has changed over time because there is still much to be discovered about the disease, how it spreads and, most importantly, its origin. There is a consensus that the first outbreak of the new coronavirus is linked to wet markets in Wuhan, where live and dead wild animals are sold. It is still unclear how and when the SARS-CoV-2 virus began infecting human species. Researchers do not know whether the virus appeared there or "took advantage" of that location to spread from one person to another. "If you ask me what is most likely, I tell you that the virus comes from markets selling wild animals," Yuen Kwok-yung, a microbiologist at the University of Hong Kong, told the BBC. ${ }^{6}$

The doubts remain. The first cases of Covid-19 were officially reported at the end of December, but a study conducted by physicians in Wuhan, published in January by the medical journal The Lancet, found that the first known case of covid-19 in a human had occurred weeks earlier.

Chinese virologist Li-Meng Yan, who fled to the United States in April this year, claims that her country has lied regarding the coronavirus and knew as early as last December about the ease with which Covid-19 is transmitted between humans. Yan made these statements in a recent interview on Fox. The virologist, who worked at the Hong Kong University of Public Health, stated that the Chinese government knew about the SARS-CoV-2 danger before it informed the World Health Organization (WHO) of the outbreak in China's Wuhan region on December 31. She reports that she began studying the virus in December 2019 from Hong Kong and was in contact with other virologists who were in mainland China and had more information on the virus. She allegedly found out that the virus was spreading very fast from person to person, something that was still unknown, and reported her findings to Dr. Leo Poon, an alleged WHO contractor who concealed her research and asked her to keep quiet, hinting that she might lose her life. ${ }^{7}$ The virologist accuses the WHO of "corruption" and complicity with the Chinese government, a hypothesis that President Donald Trump has supported since the beginning of the pandemic. The WHO has denied the virologist's claims and told Fox that "a lot of people work for them as advisors," but they have no evidence that Yan, as she claims, worked for a WHO reference laboratory specializing in viruses and pandemics.

Initially, when the first cases appeared in China, the virus was thought to attack only the lungs, but in the most severe patients it causes inflammation and blood clots, attacks multiple organs and causes lifethreatening problems. 
In this sense, it can be stated that this coronavirus can be lethal, or it can be no big deal. It can leave a person in the intensive care unit hooked up to a ventilator, isolated from family and facing a lonely death; or it can just come and go without leaving a mark, like a phantom pathogen that is more rumor than reality.

After six months of a pandemic that has killed more than $564,924^{8}$ people around the world, scientists are still trying to understand the vastly changing nature of Covid-19, the disease caused by the virus. By May 2021, global Covid-19 deaths, according to UN estimates, would be between 6.8 and 10 million, two to three times higher than those reported. ${ }^{9}$

The questions being asked are: Are some coronavirus strains more dangerous? Does a patient's blood type affect the severity of the disease? Do other genetic factors play a determining role? Will some people be partially protected from Covid-19 because they have had recent exposures to other coronaviruses? ${ }^{10}$

Furthermore, six months after the first coronavirus case was reported in China, a consensus began to emerge among scientists concerning how people become infected. Contrary to what was initially believed, many researchers assure that it is uncommon to become infected with coronavirus by entering into contact with a contaminated surface, as well as during a fleeting encounter in the open air with infected people. In contrast, one of the most common circumstances for contagion would be face-to-face encounters and interactions between people over prolonged periods of time. The scenarios where the contagion risk is high are mass events, poorly ventilated spaces and places where people talk or sing loudly.

These recent discoveries and agreements among the scientific community helped companies and governments to develop reopening strategies that did not endanger public health, while economies were getting back on track. Strategies include installing acrylic barriers or dividers, requiring and extending the use of face masks in stores and other transit spaces, implementing good ventilation systems, and keeping windows open when possible.

The most recent research results, looking at measures taken in different cities, showed that quarantines (including stay-at-home orders, bans on large gatherings and business closures) did indeed prevent millions of infections and deaths around the world.

However, now that the coronavirus is better known, cities can implement different mechanisms to avoid massive contagion in the population. This means improving protection in nursing homes and in homes where people live in crowded conditions, as well as reinforcing the call to maintain physical distance and the use of face masks, and reducing meetings in enclosed spaces. In all cases, recommendations for conducting a reopening include mass testing, contact tracing and isolation of persons infected or potentially exposed to the virus.

To date, health authorities have identified human contact with respiratory droplets as the principal mode of Covid-19 transmission. These can be passed from one person to another if they land in the eyes, nose or mouth. But they generally tend to fall to the ground or onto other surfaces fairly quickly. Some experts assert that the coronavirus can also be transmitted through even tinier droplets which float in the air longer than the larger ones and can be directly inhaled. ${ }^{11}$

\section{During a Time When the World Requires Cooperation, What We See Is Confrontation in Economic and Geopolitical Disputes}

The Covid-19 pandemic was compared to the greatest natural disasters and, therefore, public health, epidemiology and infectious disease professionals were aware of the problems associated with the new epidemic since the publication of the first cases of pneumonia in the city of Wuhan, China. On March 11, 2020, the Covid-19 outbreak was officially declared a pandemic by the World Health Organization (WHO), three months after the first case was detected.

Clearly globalization has played an important role in this. At the same time the new and highly aggressive virus spread very quickly throughout the world, and it took most governments far too long to understand what was going on.

The Covid-19 outbreak represents an unprecedented challenge for contemporary democracies. Despite the global nature of the problem, the response has been mainly national in the face of extremely weak global coordination, which was evident in the distribution of vaccines. But the big problems are global: water, pandemics, climate change, money. We should try to establish an agreement regarding this problem through 
coordination, just as the European Union did at some point in time. According to Javier Solana, a leading Spanish diplomat, "public goods must be governed from this perspective. There are things that are managed in this very exemplary way: airspace, but we are not capable of doing it on the ground, in energy or health". ${ }^{12}$

It is not a presumption to say that the world has lived through "two wars", the health war and the commercial war. China had to harden its tone towards the United States and respond to the latest accusations launched from Donald Trump's administration, which points the finger at Xi Jinping's government for hiding key information about the emergence of the new coronavirus.

It was a response that arose as international pressure on Beijing increased, due to its management of the crisis in the initial outbreak and after harsh criticism from the United States, France and England for concealing information in the early stages of the pandemic, thus preventing the rest of the countries from taking measures in this regard. This is combined with suspicions declared by the U.S. government that the pandemic began in a laboratory experimenting with bats in Wuhan, the epicenter of the virus. "A lie is a lie, no matter how many times it is repeated," said Chinese Ministry of Foreign Affairs spokesman Geng Shuang. ${ }^{13}$

Chinese Minister of Foreign Affairs Wang Yi stated that Washington had been infected with a "political virus" that takes advantage of "every opportunity to attack and defame China". Some political forces in the United States are taking China-U.S. relations hostage and pushing our two countries to the edge of a new Cold War," the chancellor told reporters. Wang also accused U.S. policymakers of "spreading rumors" to "stigmatize China," where the new coronavirus emerged late last year. However, the minister stated that China is "open" to international cooperation regarding the identification of the origin of the lethal virus, which must be "professional, fair and constructive" and without "political interference". ${ }^{14}$

\section{Preliminary Assessments of Government Performance: The Importance of Leadership}

In the case count and the death count, international organizations have the responsibility to monitor the different countries. Most of the time they do so by comparison, although public opinion also does so, based on official information or articles written by journalists. However, it is not easy to compare countries with different populations, different approaches regarding the problem, different health systems, different epidemiological surveillance and different demographic characteristics.

However, leadership, one of the most properly political concepts, may be one of the most difficult to define. Now that we are in exceptional conditions in almost half the world and we see the statements and actions of so many national and international leaders, we cannot avoid making a judgment about their leadership capacity.

For example, Fernando Vallespín, a Spanish scholar, states that under the conditions of normal politics, most leaderships are constructs of communication strategies, in other words, they are simulated and when they are in exceptional conditions, they remain bare, since there is no communication politics capable of supporting them, unless, and herein lies the question, they have certain specific attributes, some natural condition, not induced, that reveals their authentic status. "The great losers in this crisis are the "strong men", the populist macho men, and all those who are fighting against the virus as a warlike confrontation". ${ }^{15}$

The management of big crises such as the one we have experienced in 2020 and in the first months of 2021, has tested the leadership of governments around the world. In the case of the coronavirus even more, because we do not know for sure the extent of its impact. There are too many questions to be answered before a clear road map can be drawn up, so that the public can be informed about the steps to be taken once the lockdown is over. In the meantime, the social discomfort of the long lockdown has been growing, causing widespread discouragement, especially among those who find it most difficult to endure the situation. And the feeling of disconnection between the political leaders managing the crisis and the society suffering from it is also growing. Under these circumstances, the communication strategy used by those in charge to explain to citizens the situation's evolution is critical.

However, the devastating consequences of this crisis suggest that in order to manage it, it is not only the boldness or the speeches that the politicians allude to the offensive against the virus that are useful. In this sense, some leaders of several countries around the world gained visibility by taking strong decisions 
and distancing themselves from this belligerent discourse. For example, the President of Taiwan, Tsai Ingwen, was not lacking in courage and determination; The Prime Minister of New Zealand, Jacinda Ardern, or the German Chancellor, Angela Merkel, to implement immediate measures after the appearance of the first coronavirus cases in their respective countries, because they have surprised with innovative political decisions, with solidarity and empathetic gestures, such as the Prime Minister of Iceland, Katrín Jakobsdóttir, who decided to test all her citizens at a time when in many European countries testing is still used very rarely. Or the Norwegian Prime Minister, Erna Solberg, when she appeared on television to speak directly to the children of her country, organizing a press conference where adults were not allowed to be present. The recent decision made by all members of Jacinda Ardern's New Zealand government to cut their salaries by $20 \%$ as a gesture of solidarity with the current crisis is another relevant example. These are gestures that in the midst of the coronavirus storm have the power to generate a sense of consideration and closeness to citizens. ${ }^{16}$

\section{Pandemic Takes Its Toll on Leaders: "Winners" and "Losers"}

Four months after the pandemic began, Fran Ruiz Perea published a two-part article called "The pandemic is taking its toll on the leaders". The following is a summary of the journalist's comments.

Among the winners was Luis Lacalle, President of Uruguay, who just over ten days after assuming his office on March 1, the center-right leader had to announce the first four cases of COVID-19, so his administration has basically focused on dealing with the health and economic problems derived from the pandemic. His strategy of premature lockdown - even sacrificing the tourism sector, which is key to the national economy - has managed to keep the pandemic at bay.

Nayib Bukele, president of El Salvador, probably the most emblematic case of the pandemic crisis. The more authoritarian, the more popular. Coinciding with the first anniversary of his accession to power, last June 1, and two months after he decreed the militarized lockdown of the country, the right-wing leader has the almost unanimous support of the population, despite his open confrontation with Congress and the Supreme Court, and the claims of the Inter-American Court of Human Rights (IACHR) and organizations such as Human Right Watch (HRW) and Amnesty International about the growing deterioration of democracy in El Salvador.

Angela Merkel, Federal Chancellor of Germany who, at the end of last year, was considered a political corpse, worn out both in her country and in the rest of the European Union. Three months later, the Chancellor re-emerged as a world statesman, thanks to her leadership in dealing with the Covid-19 crisis. Instead of denying the crisis, like Donald Trump of the United States, she used economic resources in the application of massive tests in order to detect where the outbreaks were and to isolate them immediately.

Mette Frederisken, Social Democratic Prime Minister of Denmark, who some call the "European exception", for having managed to stop the pandemic in its tracks in Denmark, thanks to being one of the first countries in the world in declaring total quarantine and hermetically closing the border, just the opposite of its "Swedish Scandinavian neighbours", with whom they are united by a bridge.

Jacinda Ardern, Prime Minister of New Zealand, a New Zealand social democrat politician, was the first leader to close her country's borders and declare a quarantine (in early February) and can now proudly boast of having been the first country to defeat the pandemic. ${ }^{17}$ Support for the New Zealander jumped 20 points.

The coronavirus had not only killed thousands of people around the world, but sent presidents like Donald Trump to the political grave and weakened Boris Johnson, as the polls announced. Only a few are being recognized by their compatriots and almost all of them are women.

Among the losers, Ruiz Perea highlights Donald Trump, President of the United States. The "Chinese virus", as the Republican liked to say, destroyed the New York tycoon's career in the November 3, 2020 election. On May 28, the day the United States reached the figure of 100,000 deaths due to the pandemic, which the president assured would end in April "with the heat" and for which he prescribed "injecting chlorine", the Gallup company conducted a macro poll on the president's popularity until June 4. The result was a disaster because of his intention to be reelected. 
Boris Johnson, Prime Minister of the United Kingdom. The Tory leader not only became infected with COVID-19, but had a late preventive reaction at the beginning of the pandemic, and could have avoided a greater number of British deaths if he had quickly established lockdown.

Jeanine Áñez, interim president of Bolivia. The pandemic ruined the March elections -in which the current conservative president and opponent of Evo Morales was the clear favorite- and it destroyed the hopes of Áñez -also infected by the pandemic but asymptomatic- to be legitimized through votes in that country's elections.

Jair Bolsonaro, President of Brazil, one of the most surprising cases is that of the ultra-right-wing leader, the biggest proponent of pandemic denialism and the ultimate detractor of lockdown. The controversial behavior of the ex-military officer - who after the death count soared stated "and what does it matter to me" - has literally split society in two. According to a poll conducted by the Datafolha institute, $50 \%$ of those interviewed in May 2020 rated the leader's management to stop the new virus as bad or terrible, compared to the other $50 \%$ who support his management. ${ }^{18}$

Andrés Manuel López Obrador, President of Mexico. From February to May 2020, and coinciding with the outbreak of the health crisis, his popularity declined significantly. Although the pollsters' percentages may vary, the downward trend of his approval was coincident. ${ }^{19}$

\section{The Pandemic Problem in Mexico: How Did the Government Deal With the Onset of the Crisis?}

In anticipation of the pandemic's arrival in Mexico, UNAM specialists warned that it would be very risky for the federal government to commit the arrogance of considering it had Covid-19 under control, and drew attention to the fact that there was no surveillance of border cities (the focus was on the city of Tijuana) with the United States, a country where the disease was already widespread by mid-March $2020{ }^{20}$ The Covid-19 pandemic could not only cause a health crisis -since added to pneumonia and influenza its presence would be lethal-, but also an economic catastrophe and if the virus spreads throughout the country, it could affect public resources allocated to priority infrastructure works of the $4 \mathrm{~T}$, or even worse, to the social programs promoted by Andrés Manuel López Obrador. ${ }^{21}$

Despite the fact that almost everyone had begun to take measures in order to seriously face the pandemic, President López Obrador was criticized for not changing his position or his messages: "he minimizes the importance of the emergency, calls for calm and trust in his government and once again lashes out against the media and opposition politicians, whom he always branded as "conservatives"". ${ }^{22}$ However, facing the situation, Mexico confronted the current emergency with about 3,000 intensive therapy beds equipped with artificial ventilators, but needed about 20,000 beds to attend to the eventual victims ${ }^{23}$. In response to this situation, the Mexican government reached an agreement with the private medical sector, which represented a ground-breaking alliance to strengthen healthcare capacity and medical institutions for the public. ${ }^{24}$

The coronavirus would find a suitable victim in the economy's informal sector, which employs half of the working population. Unlike the formal sector, it lacks social protection, fiscal incentives and government support. It is about the population that is "on the margins of the system" and that will not be able to confine itself because for them to stop working is to stop eating. ${ }^{25}$

In addition to its health effects, the coronavirus could directly or indirectly affect 40 million formal and informal workers, and poverty could reach $48 \%$ of the country's population. In this regard, it was stated that "institutional efforts to bring millions of Mexicans out of prostration would be left in tatters" and experts also agreed that in a matter of weeks Mexico could go back a couple of decades in social matters. ${ }^{26}$

\section{The 12 Financial Supports Promoted by the Government in Order to Face the Pandemic}

The following is a summary of the supports provided by the federal and state governments during the pandemic so that people could have an income during the quarantine period.

Most of the financial supports were focused on Mexico City and only a couple of them were classified as federal, however, it was pointed out that each entity had similar scholarships and grants. 
1. Pension for the elderly. Aimed at people over 65 years old living in indigenous communities and senior citizens over 68 years old in the rest of the CDMX; during the month of April, two bimonthly payments of 5,340 pesos were made.

2. Financing for micro-enterprises. Credit for micro-enterprises in Mexico City affected by the Covid-19 health emergency so that they can continue operating and preserve jobs. (The loan amounts to MXN 10,000 for a term of 24 months with a grace period of 4 months. Interest rate of $0 \%$ and no guarantee is required).

3. My scholarship to start. Scholarship intended for students of public kindergarten, elementary school, and high school, as well as those enrolled in Centers of Multiple Attention at kindergarten, elementary, high school, and work level.

4. Soup kitchens. This program is available to the entire population of Mexico City. There is a nominal fee of $\$ 11.00 \mathrm{MXN}$ per ration.

5. Medical kit against Covid-19. Packages containing products, medicines and food necessary for keeping a person with Covid- 19-related symptoms at home without having to go to the hospital.

6. Support for school uniforms and school supplies. Scholarship for students of public kindergarten, elementary schools and high schools.

7. Financial support for working mothers. This program seeks to guarantee that mothers, fathers and single guardians who work, seek for employment or study have the necessary resources for the care and attention of their children.

8. Welfare packages. Focused on traders and micro-entrepreneurs who have a micro-business that has been in operation for more than six months and who for different reasons have not had access to the services offered by the traditional financial sector.

9. People with disabilities. Aimed at children, teenagers and young people from 0 to 29 years old who have permanent disabilities; indigenous and Afro-Mexican population from 30 to 64 years old and non-indigenous adults from 30 to 64 years old who live in areas with a high or very high degree of poverty.

10. Unemployment insurance. Monthly economic support of $\$ 2,641.15$ for up to 3 months. In addition to promoting the job reinsertion of people through training and job placement. (resident population of the CDMX over 18 years old)

11. Enterprising women. Its purpose is to promote the financial independence of women and contribute to reducing the gender gap in economic development through credit for entrepreneurship, for the creation or consolidation of micro-businesses or for the increase of assets and greater access to technology by women entrepreneurs.

12. Mercomuna Program (market, community, food and supply). Delivery of benefits to the vulnerable population during the health emergency ${ }^{27}$

In the midst of the statements regarding the certain "hospitals overcrowding", the Mexican business community was still waiting for the federal government to coordinate with the states and sectors of the country in order to face the health emergency and the looming crisis. One of them, the leader of the Consejo Coordinador Empresarial (Business Coordinating Council, CCE), regretted that, despite the President's encouraging speech about opening up to private investments, these faced many obstacles, as there was no governmental plan against the contingency. ${ }^{28}$

From the perspective of specialists in international finance, with the low rating of the debt by Standard \& Poors, Mexico had already lost the battle in the "war economy that is based on the global health emergency, which coincides with the financial crisis and aggravates it"; therefore, "like the U.S. government, López Obrador's government had to make quick decisions to support the most affected sectors and boost those that can overcome the situation and sustain a certain level of growth". ${ }^{29}$

The "economic storm" affected key sectors of the industrial, tourism and restaurant economy. Business leaders forecasted that the ensuing economic crisis would be worse than that of 2008 and 2009, which would require the support of the state and federal governments to avoid a massive closure of companies. 
However, some of them were benefited by the pandemic itself, taking a breathing space in relation to the depreciation of the peso against the dollar, as was the case of Televisa and TV Azteca.

On Tuesday, March 24, 2020, in a speech made by Ricardo Salinas Pliego, President of the Salinas Group, (for many an unfortunate message two weeks after the restrictive measures had begun in the country, but which will certainly go down in history as a demonstration of how businessmen think), he called on Mexicans to go out to work, because he assured that the Covid-19 was not lethal, as the economic crisis was: "Today we are in a bad way, the streets are empty, schools are empty, hotels are empty, restaurants are empty, parks are empty, there are no people. This can not be possible, this can not be possible. Life must go on. This virus definitely exists, but it is not highly lethal, we must forget the wrong equation, that virus is equal to death. This is not true. The way things are going, it looks like we won't die because of coronavirus, but we will die of starvation." 30

On May 4, 2020, President Andrés Manuel López Obrador published a text entitled "Some lessons from the Covid-19 pandemic", in which he advanced what he considered to be some lessons arising from certain fundamentals and palpable results.

Firstly, he stated that "it is a fact that public health systems during the neo-liberal period were not considered a priority by most governments of any political or ideological tendency in the world. In China, for example, despite being the country with the highest economic growth in recent decades, hospitals were built on an emergency basis; in Europe and the United States the scenes of the seriously ill patients waiting to be treated in intensive care units have been heartbreaking; in our country it has become evident not only the lack of beds, ventilators or protective equipment for health sector workers but, most seriously, the shortage of medical personnel, above all, of specialists in attention to the different diseases."

"But perhaps the greatest indifference or irresponsibility of governments that the coronavirus has revealed is the neglect, for decades, of chronic diseases such as hypertension, diabetes, obesity and kidney disease, which have increased as a result of the consumption of industrialized food products known as 'junk food', and the absence of nutritional education and promotion of physical exercise and sports activities." ${ }^{31}$

For López Obrador, the coronavirus was not responsible for the looming economic catastrophe, but the pandemic had revealed the failure of the neoliberal model in the world. Considering that his government is certainly supporting different sectors through a set of social programs that include all its programs as a whole, he extended his reasons why Covid-19 had come to precipitate, in the midst of a tremendous exhaustion, the collapse of the neoliberal model in the world, for which he considered that it would be absurd to insist on applying that same paradigm to face the current economic crisis.

Through the publication of the document: The new economic politics in times of coronavirus, he ${ }^{32}$ informed that his government had decided to free funds and not to put the country further into debt, and for this purpose he issued a Decree dated April 23 of this year ${ }^{33}$, which states the following: "In accordance with the criteria that govern us of efficiency, honesty, austerity and justice and in view of the world crisis of the neoliberal model, which undoubtedly affects us, I propose the urgent and categorical application of the following measures. I). No workers will be dismissed, but there will be no increase in personnel; the salaries of senior public officials will be reduced by up to $25 \%$ progressively. In other words, the higher income earner will contribute more and the discount for the lower levels will be less. Likewise, senior public officials will not receive Christmas bonuses or any other year-end benefits. The concept of senior public official applies from deputy director to president. II). $75 \%$ of the available budget for general services items and materials and supplies will not be used. This also includes the allegedly committed. Ten undersecretariats are cancelled and employment is guaranteed at the same status and with the same income to those who will leave such positions. III). The suspension of labor activities with pay for those who are already in this situation due to the Coronavirus pandemic will be extended until August 1. IV). Half of the offices shall remain closed with the exception of those that directly serve the public or those that are essential for the welfare of the people. In this period, an effort will be made to relocate public servants according to priority in order to stop renting buildings, vehicles, warehouses and real estate, among other savings. V). Government actions and spending are postponed, with the exception of the following priority programs (38 priority programs are recorded)..."34 


\section{How Mexico Avoided Hospital Collapse}

Mexico faced the Covid-19 pandemic with a weak and certainly improvised hospital system, the consequence of decades of neglect and under-investment in which preventive medicine was neglected in favor of medical-hospital care. Today it is found that comorbidities such as overweight are the responsibility of individuals, but where are the preventive health programs? For many years, the State's lack of interest was combined with the idea that a hospital space gives more visible and immediate results, while preventive medicine requires long-term and constant actions ${ }^{35}$

In this sense, it is surprising that it is asserted that Mexico has been one of the few countries that have reduced its life expectancy without having gone through a war process. Since 2011, it has been verified that, in the first place, this had been the result of violence, to which chronic non-transmissible diseases, obesity and diabetes were added. ${ }^{36}$

The hospital response plan of the Coordinating Commission of National Health Institutes and High Specialty Hospitals (CCINSHAE by its Spanish acronym) was a strategy focused on "hospital restructuring", which is defined as the adaptation of hospital areas other than the intensive care unit to transform them into units for the care of critically ill patients who require or may require mechanical ventilation.

It was necessary to implement a strategy in order to deal with the worst case scenario of a new, highly transmissible virus, which produces a multifactorial, multi-stage, multi-systemic, extremely complex and lethal disease, and that in January 2020 those responsible in the government considered that the virus would be similar to the influenza virus and it was not the case. ${ }^{37}$

Additionally to the necessary infrastructure and equipment, medical and nursing human resources trained in the use of equipment and in the treatment of critically ill patients were also required. In this sense, although the restructuring achieved the objective of avoiding hospital overcrowding ${ }^{38}$ and, based on this, the government established the operation of epidemiological traffic lights, this should not be seen as an achievement in itself; although there may have been availability of beds, the health system had no specialists in the treatment of critically ill patients, and general practitioners had to be hired in order to care for the patients. $^{39}$

The main project of the 2018-2024 six-year term was kept during 2020, but it was difficult to maintain the momentum of building a single, public, universal and free system. The starting point for some specialists is to recognize that the health system in our country has been developed historically, but in a divided manner, i.e. with differentiated access mechanisms between labor social security, the population without social security or "out of pocket", or through payment to insurers or private providers. In addition, given that it is divided, each of these categories has different ways of accessing services, but it is generally the population without social security and residing in remote rural areas who receive the worst care. ${ }^{40}$

Thus, the trajectory of the Sistema de Salud para el Bienestar (INSABI) created in December 2019, the date on which the SNPSS- Seguro Popular was repealed can be considered eventful. At least 9 states of the federation did not sign the general agreement with this entity, which specifies the concrete form of the federalization of services. In other words, a new segment has been created in the public health system, called INSABI, without the elimination of state services, which in practice work as they did with Seguro Popular.

Under this situation, it is important to highlight that the Covid-19 pandemic established new challenges and demands the development of clinical skills for health professionals. In order to be at the forefront, the health system must consider as an opportunity the need to open new horizons to its health professionals, since the reality demands new clinical skills.

It is important to retake the discussion of how and with whom to build a public health system: with a vertical approach based on a limited conception in this area and biosecurity or with a horizontal and participatory design ${ }^{41}$, since it is an important discussion not only during this pandemic, but also to know how to rebuild a new public system for the years to come and to face similar circumstances in the future.

However, Mexico's aspiration to turn health into a "common good" can only be achieved with big capital investments and not only by decree, "there is a long road ahead for the population to have universal care; and there is still a long way to go in order for the common goods of health in Mexico to cover 
preventive, palliative and rehabilitative medicine and with an adequate epidemiological surveillance in accordance with global standards and aspirations". ${ }^{42}$

In this task it is fair to acknowledge that the world has been caught in a perfect storm of rising rates of chronic diseases, persistent infections and public health failures that have allowed an escalation of deaths during the Covid-19 pandemic. In different parts of the world, there has been an increase in the total number of deaths as the epidemic has progressed. This phenomenon has been called excess mortality or high mortality.

To date, there are a number of significant scientific studies documenting this phenomenon in European countries, the United States and Latin America. In Mexico, reports regarding excess mortality have also been published. The increase in this mortality, in accordance with the COVID trend, may have several explanations. In this case, it is of interest to analyze the rise in relation to the social determinants of deaths. The first is technical and refers to deaths that were actually caused directly by the coronavirus, but have not been recorded as deficiencies in the registry systems. These failures can be general in a country, but are more common in poor areas or regions. They can be a substantial proportion of excess deaths when the quality of administrative records is poor. It should be taken into account that they produce a bias in the same direction, both in underreporting and in other social determinants. In other words, underreporting is greater among the poor and so is poverty itself.

Inequity in socioeconomic conditions can have an impact on several aspects. A first group is related to the unequal distribution of comorbidity, e.g., obesity, diabetes, hypertension, which tend to occur more frequently among the poor population. The same applies regarding access to detection, diagnosis and treatment of Covid-19, whether in clinics or hospitals, in both rural and urban areas in need. This lack of access has increased as a result of the restructuring when, in particular, public institutions have deferred care for non-COVID conditions, leading to higher mortality from untreated causes. ${ }^{43}$

\section{Andrés Manuel López Obrador Chooses to Reaffirm Government Austerity in the Face of the Demand for a Financial Bailout}

After announcing his economic program in the face of the pandemic, it was reported in many media that President López Obrador had rejected ambitious stimulus packages, even as millions of Mexicans were at risk of falling into poverty, but also that he opposed financial bailouts and was wary of saddling the country with debt.

In order to avoid the worst economic consequences of the pandemic, governments around the world have rushed to pump money into their faltering economies by raising billions of dollars to generate stimulus in order to keep businesses afloat and keep employees on the payroll, with the thinking that when the pandemic finally ends, economies will not have to start from scratch to recover.

European countries had spent trillions to counter economic devastation and are considering raising more than $\$ 800$ billion in collective debt to prevent economic collapse. Some Latin American neighbors of Mexico have acted decisively: Chile, Peru and Brazil have approved packages worth 8 to 12 percent of their economies.

AMLO met with Mexico's top business leaders more than once, who asked him to make more progress on the economy. They warned that tens of thousands of people were losing their jobs. Small and mediumsized companies, which employ more than 70 percent of Mexico's workforce, were becoming cashstrapped. They argued that the government had to intervene. The data were incontestable. The pandemic could have the worst economic consequences Mexico has seen in a century, according to economists. More jobs were lost in April than were created in the entire 2019.

However, against estimates that potentially as many as ten million people could fall into poverty by 2020, between small loans to businesses and spending for cash transfer programs to the poor, the young and the elderly; most economists estimate that the increase of spending in Mexico would be less than one percent of its economy, a small amount compared to many large countries. The actual report from the government is necessary. 
The economic damage from the pandemic was unavoidable. But, in the view of many economists, the difference between a widespread and prolonged crisis and a major recovery will depend on the government's ability to help companies and workers stay afloat until the worst is over.

Part of the protest against López Obrador's handling of the pandemic was his failure to offer a comprehensive economic rescue proposal and his reliance on a commitment to large infrastructure projects. The president's resistance, according to those who know him, is based on his interpretation of the country's problematic financial history and that even as oil prices collapsed and experts question the usefulness of the oil refinery, the president has remained steadfast in his commitment to build a refinery. However, while critics demand that he shut down his infrastructure projects and channel the money into a bailout package, some economists say it would not be enough anyway. ${ }^{44}$

\section{López Gatell's Forecasts on Mexico's Death Count Contradicted}

On June 4, 2020, Hugo Lopez-Gatell, Deputy Secretary of Prevention and Health Promotion, estimated up to 35,000 deaths in Mexico due to the coronavirus. However, the Institute for Health Metrics and Evaluation (IHME) of the University of Washington assured that Mexico will exceed 50,000 deaths due to coronavirus, which contradicts the 35,000 deaths projected by López-Gatell and warned of an increase of more than six times compared to its previous forecast of around 7,000 deaths. Mexico has seen an explosive growth of the coronavirus and must enforce existing mandates and measures, as well as increase testing to stop a fast-moving epidemic and reduce transmission of the virus, said Christopher Murray, director of the IHME.

The Institute's analysis indicates that there will be 51,912 deaths in Mexico on August 4, with a possible minimum range of 37,397 deaths and a maximum of 75,516 deaths. In the case of Mexico City, the pandemic's epicenter, 7,435 deaths were expected, with an estimated range of 5,808 to 9,692 deaths; higher than the 3,414 estimated on May $12 .{ }^{45}$

Now, according to the model created by Youyang $\mathrm{Gu}$, an independent data scientist and graduate of the Massachusetts Institute of Technology, the projection was that Mexico could reach nearly 132,000 deaths from Covid-19. The document provides three different mortality ranges for 70 countries and U.S. states: high, low and projected scenario, the latter having the highest probability of occurrence.

The projection of 132,000 deaths for Mexico is the data for the intermediate scenario; in the worst case scenario, there would be 212,000 deaths by the first day of September 2020; in the best case scenario, the number of deaths would be 37,000. According to this projection, the peak of the daily death curve in Mexico would occur on August 10, 2020. The pandemic's peak, with the highest number of estimated new infections, would be July 22 of that year.

The information, available on the covid19-projections.com website, is calculated by a simulation made with artificial intelligence, automated learning and based on the mathematical model used by epidemiologists to calculate infection curves.

In contrast to the model used by the Mexican Ministry of Health, the MIT researcher describes its general methodology, its confidence intervals and provides key data such as the infection rate, which is the number of people who can contract the disease by interacting with a carrier. ${ }^{46}$

\section{What Was the Real Intent of the Debate Behind the Covid-19 Figures in Mexico?}

As we previously stated, part of the public debate in Mexico on the official health treatment of Covid19 has been trapped in the data point, the statistics of infections and deaths; as in other parts of the world, there is no generally accepted methodology or criteria, so governments are designing their emerging health policies in a variety of ways and with different results.

In Mexico, as the journalist Julio Hernández López states, there was a sort of declaratory and political clash between governmental positions and some of those who have been health secretaries in previous federal administrations (José Narro, Julio Frenk and Salomón Chertorivski). Some media have also highlighted the alleged differences between the official and actual number of deaths and contagions. According to these positions, reality is being dissimulated to adapt it to the arithmetical needs of the government of President Andrés Manuel López Obrador. 
The direct target of these disparaging remarks has been the central character in terms of public strategies before Covid-19, the Deputy Secretary of Health, Hugo Lopez-Gatell. We agree that, in essence, beyond the technical and scientific divergences, what is at the heart of the discussion is not only epidemiological issues, but also the clash between the current administration and the people, interests and visions that for decades controlled the top of the health structure in Mexico, the management of resources in this area and, consequently, the assignment of contracts, grants and benefits.

Only one former Secretary of Health is in line with López Obrador: Juan Ramón de la Fuente, who is Mexico's permanent representative before the United Nations. Others are outspoken opponents, especially José Narro, who was Secretary of Health during the highly controversial administration of former President Enrique Peña Nieto. He was also an aspirant in 2018 to be presidential candidate for the Institutional Revolutionary Party, which finished third in the election and was defeated by López Obrador's party.

"In addition to the structure of the Ministry of Health, the Mexican health system has two agencies that, for decades, have been virtual political spoils: the Mexican Social Security Institute (IMSS, which is financed through workers' and employers' quotas), and the Social Security and Services for State Workers (for federal government employees). It was common in the political past for people close to the presidents of the Republic in office, or pushed by strong groups or politicians, to be appointed as directors of both agencies, and for their budgets to become banquets for an almost institutionalized corruption". ${ }^{47}$

This long-deteriorated health structure was confronted by the current government in order to plausibly correct these errors. However, the contract review and the new "purged" allocations generated shortages, problems and anger in some segments in need of adequate medical care, functional devices and sufficient medicines. Between the legacy inherited from previous governments and the late or mistaken management of the new administration, the operating conditions of a health system that many years ago ceased to function in a more or less acceptable manner have worsened. The coronavirus crisis reached this critical stage.

According to Hernández López, as of May 2020, "the statistics and evidence do not show a national health disaster in Mexico, despite the uneven compliance with the recommended social distancing measures. Amidst the entanglements and controversy regarding Deputy Secretary Lopez-Gatell's narrative and the officially reported day-to-day figures, there has not been a collapse of a previously damaged health system in the country".

It is true that the technical matters, data and statistics are only an instrument of discussion in a Mexico polarized in political and ideological terms, a phase of a fierce process of debate and repositioning that will have as an intermediate point of outcome the federal parliamentary elections -and of 15 state governorships, to be held in 2021 and, as a critical point, the real mother of all battles: the presidential elections of 2024 . The clash between these two views on the use of resources and privilege politics is at the heart of the dispute over the figures. ${ }^{48}$

In the Mexican case, the Deputy Secretary of Health Hugo Lopez-Gattel, (who at the end of June 2020 began to be criticized for his style of responding day by day to questions from journalists and critics regarding the evolution of the pandemic, after four and a half months of lockdown and with steps backwards towards the "reopening"), stated that Mexico faced the pandemic with a health system with enormous deficiencies. This system underwent a hospital restructuring for which the intervention of the Navy, the Mexican Navy and the Mexican Army were decisive, from 645 to more than 900 medical units. And that in despite of the people who do not have such a clear risk perception, it must be acknowledged to the Mexican people that if they had not followed the call of the mitigation phase ("stay at home") we would not have achieved a lower number of contagions, of a pandemic that in the country was presented with a "slow speed", (phase 3 was extended) reason for which we "achieved a lower number of contagions", but with a resolution phase 4 that "did not come soon". 49

Although there are still no systematic evaluations about sociological characteristics of the deceased population that present reliable statistical data, we will refer here to a study by a researcher of the UNAM that has been published in different printed and electronic media, whose partial results indicate that the Covid-19 pandemic has affected the most vulnerable population in Mexico and in particular people with little education, since of every 10 Mexicans who died due to the coronavirus, seven $(71 \%)$ had an 
elementary school education or less (incomplete elementary school, kindergarten or no studies). In addition, $46 \%$ of the deceased patients were retired, unemployed or had an informal job. More than $50 \%$ of these deaths occurred in medical units for the population that did not have access to social security. Drivers, assistants, laborers and the like, street vendors, artisans, factory, repair and maintenance workers comprise this low-income sector. ${ }^{50}$

\section{Reflections on the Covid-19 Pandemic Experience That Add to the Story}

The historian Claudia Agostini states that historical experience shows that when a pandemic ends, there is a kind of collective amnesia accompanied by the absence of a systematic and tenacious foresight to deal with subsequent health emergencies ${ }^{51}$. In addition, the historical study of pandemics shows that, in relation to Covid-19, as in the past, the management of absolute figures of deaths is an issue that can be used politically to praise or denigrate the actions of governments, since the social demand to know the correct number of dead people is a widespread problem, but no country in the world has an accurate record, because many people have died at home and did not go to the hospitals, which makes it difficult to register.

The historical study of pandemics shows that they generate resilient or incredulous societies; this means that some societies patiently and resiliently pass through times of doubt where certainties are lacking; but others do not, because they have less confidence in science, medicine or their governments. In this regard, the historian Diego Arnus states "because societies have not been able to capitalize on previous epidemic experiences and understand that these extraordinary events are, to a large extent, inevitable, but they also begin and end". 52

Karina Ramacciotti states that historical studies also show that those who remain in the pantheon of heroes who face pandemics are almost never those who are dedicated to the patients' care. Nurses and even cleaners in hospitals, not only suffer the lack of empathy from the people who attack them, but also from the institutions that keep them without recognition or salary improvements (Mateos Vega, 2020e).

It is true that the neoliberal politics that many governments in the world adopted during the decades of 80 s and 90s of the 20th century are the cause of epidemics such as Ebola, AIDS, influenza A/H1N1 and now this new coronavirus, but historical studies show that they kill fewer people than long-term diseases, but they are - as Marcos Cueto Caballero states - of great intensity and draw more attention, because they involve a great number of actors who discuss the subject. These are moments when the relationship between science and politics is magnified.

In a pandemic situation another issue that comes up on a constant basis is stigma. The historian Marcos Cueto Caballero states in this regard: "If in the Middle Ages the Jews were blamed for leprosy, in Peru and many Latin American cities, when there was bubonic plague, the Chinese were blamed. In the 1990s, President Alberto Fujimori attributed cholera to the 'dirty people', as he called the people who lived in poor urban areas and who, according to him, did not like to wash their hands, without taking into account that 50 percent of the population did not have access to water". ${ }^{53}$

The new coronavirus has been an unknown agent, just as smallpox was in 1520 for the indigenous Mesoamerican population, or plague was for Europeans in 1348. One of the mysteries of scientists about which there is no definitive answer is how lethal is it? By the middle of 2020 in most countries, about 20 percent of all confirmed Covid-19 patients become ill enough to require supplemental oxygen or more advanced hospital care, according to Janet Diaz of the World Health Organization's emergency program. ${ }^{54}$

We must consider, however, that the main lesson that pandemics have taught mankind is resilience; that is to say, societies have shown that they know how to coordinate themselves in order to face these tragedies and one of the great tools, according to the medievalist Martín Ríos Saloma is hope, which has to do with the idea that "just as an important part of the population survived in the past, so will we survive" ${ }^{25}$. In contrast to what we are living now, in the Middle Ages disease was understood as a consequence of a person's sins or the corruption of a society, and punishment was sought to be stopped in collective prayers, since there was no scientific answer to the crisis. 


\section{CONCLUSIONS}

The pandemic caused by Covid-19 in just a few weeks, and with an unprecedented capacity to reach all corners of the world, drastically changed the political agenda of the States. First, the classic features of the presidential system have become apparent. Presidential power has been strengthened, weakening the control mechanisms of other institutions, centralization has been reinforced, and the weakness of the parties has once again become evident.

A challenge for governments has been the implications on federalism in some countries, since the federal government centralized health decisions, or left most of the decisions to the states and they made very different decisions, two examples of this situation are Brazil or the United States. ${ }^{56}$

It should be noted that both in Spain (as in Mexico) the mainstream media, the spokespersons of the political or economic groups, blame the left-wing central government for what has been done and for what has not been done, despite the fact that the responsibility for health care has been in the hands of the rightwing autonomous governments in Madrid, Catalonia, Galicia, Andalusia, Castile and Leon and Murcia for years.

Secondly, control mechanisms have been applied to society as never before and the precariousness of health, which, together with education, constitutes one of the basic pillars of the politics, has been highlighted. These are countries where health coverage is deficient and has been commoditized to such an extent that there is a huge gap between the private and public spheres to the detriment of the latter. The percentage of GDP allocated to this area is derisory and far insufficient to confront a pandemic. On the other hand, these are societies in which inequality pushes millions of people to the marginalization. Half of the population, which on average is informal, was pushed into limbo and for the fourth part, who live under minimum housing conditions, the official message to stay at home easily irritates. The social assistance programs implemented may be propaganda gimmicks more than anything else. ${ }^{57}$

Finally, panic before the worst economic recession in half a century with devastating consequences for majority sectors of the population generates a panorama of maximum uncertainty that is traumatic. The huge indebtedness of weak states, with outdated fiscal policies and economies heavily dependent on the foreign market based on the exploitation of non-renewable natural resources and environmental destruction, augur a scenario of precariousness that, nevertheless, fuels the fuse of authoritarian responses and the revival of social mobilizations in the medium term.

We must recognize that it will be a long transition to a new "normalcy" as we gradually emerge from the health, emotional and economic crises. The capacity for resilience will depend on the political, social and economic systems. To achieve this, we need a political and administrative agenda that will lead us to a new paradigm, i.e. a new model for the organization of life, in order to build a new governance.

Manuel Alcántara, a Spanish professor and scholar of Latin American governments, published an article on June 3, 2020, in which he stated that at the end of 2019, "Latin American countries, without ignoring the big differences that require individual analysis, offered an image of fatigued democracy that was projected in the aforementioned discontent, in the distrust of institutions and in the dissatisfaction with the functioning of the prevailing democracy. People identified less and less with the parties that were taken over, in presidential forms of government, by individuals with self-centered aspirations. In addition, party systems showed high fragmentation and electoral volatility. As for the States, after two long decades of neoliberal prescriptions and their consequent shrinkage, which limited their ability to intervene through public politics, they possessed minimal capacities. This applied to liquid societies with high rates of informality where the cultural empire of neoliberalism had intensified individualism and egotism".

This scenario has been radically disrupted just as the end of the first half of 2020 was reached by the Covid-19 pandemic. Although it had an impact in Latin America with a certain lag in relation to Europe,

its scope in national terms has also been very different at a time when the region is at the heart of the pandemic. While Costa Rica, Paraguay and Uruguay have had a very limited level of infection, the neighbor of the last two countries, Brazil, holds the second place in the world in terms of both deaths and number of people affected. Mexico, Peru, Ecuador and Chile also have high rates in absolute terms. The extent and 
impact of the virus in Nicaragua and Venezuela is not really known, so he proposes five points to define this agenda: authority, the State, the nation, leadership and institutionalized virtuality. ${ }^{58}$

In face of uncertainty, we will say that pandemics and "quarantines" in history reveal that alternatives are possible, that societies adapt to new ways of life when necessary for the common good. This situation is appropriate for thinking about alternatives to the ways of living, producing, consuming and coexisting in the early years of the 21 st century.

There are many proposals to improve social conditions ${ }^{59}$, but in the absence of real alternatives, it will not be possible to prevent the outbreak of new pandemics which, as everything suggests, could be even more lethal than the current one. Surely there is no shortage of ideas about possible alternatives, but can they lead to political action in order to achieve them? For example, decisively addressing climate change, ecological unbalance and preserving biodiversity.

In the current situation, it is unlikely that Covid-19 can be eliminated, Mike Ryan, Chief of Emergencies at WHO, explained on July 10, 2020. "We have to be prepared to move forward or backward (in reopening countries), depending on what the data indicates and accept the fact that in our current situation it is highly unlikely that we will be able to eradicate or eliminate the virus." He pointed out that the advice to countries has always been, first, to open slowly and gradually, through different reopening phases, in order to ensure that the data on the virus is clear and can indicate where the problem of contagion lies. He added that, as WHO and other scientists around the world have pointed out, there is a risk that, when a country's lockdown ends, the disease could re-emerge. "If the virus is present, it will potentially take every opportunity to be transmitted." 60

Covid-19 has highlighted the vital importance of the public sector, but also its inadequacies. The problem of the health system, economic support for vulnerable groups and the security problem.

Finally, the proposal that some countries have been gaining ground for a difficult but necessary reformulation of the social pact, as well as the promotion of a universal basic income, although in the case of Mexico, the chronic budgetary fragility of the State has reopened a discussion linked to its financing, since such a pact would be considered fiscal, social and productive, in which the key issue is the State's tax collection and the reallocation of public spending.

\section{ACKNOWLEDGEMENT}

I get the idea for the title of this article from the publication of the psychoanalyst Gustavo Dessal entitled: "Contagion is biological, the pandemic is political", published in the blog Zadigespaña on April 20, 2020, which I found meaningful in order to address the analysis of the relationship between the pandemic and politics. https://zadigespana.com/2020/04/09/coronavirus-la-infeccion-es-biologica-lapandemia-es-politica/.

Translated \& edited by American Publishing Services (https://americanpublishingservices.com/).

\section{ENDNOTES}

Cfr. Boaventura de Souza Santos, The cruel virus pedagogy, Buenos Aires, CLACSO, 2020, 85, pp.

Anti-virus fight: Western failure and Eastern success? https://youtu.be/tpeLQ0INCn0

An example of this that really caught the attention of this writer was this news item: "Lock her up!": armed demonstrators violated social distancing in the US to protest against the governor of Michigan. The lockdown measures (to stay at home) imposed by Democrat Gretchen Whitmer were some of the most restrictive in the country. Despite the initiative urging her supporters to stay in their vehicles, many of them got out of their vehicles and stood with assault rifles in front of the Michigan State Capitol in the city of Lansing, blocking the traffic of the streets with their vehicles. Many of the participants in the demonstration (organized by a conservative coalition) even left their vehicles and congregated on the building's staircase, in violation of the social distancing directives imposed by the regional leader. https://www.infobae.com/america/eeuu/ 2020/04/16/encierrenla-manifestantes-armados-violaron-el-distanciamiento-social-en-eeuu-para-protestarcontra-la-gobernadora-de-michigan/. 16-04-2020 
4. A conspiracy theory linking the spread of the coronavirus to $5 \mathrm{G}$ wireless technology has encouraged more than 100 incidents in April 2020, British officials stated. The attacks were spurred by the same cause, government officials said: an Internet conspiracy theory linking the spread of the coronavirus to an ultrafast wireless technology known as 5G. Under the false idea, which has gained momentum in Facebook groups, WhatsApp messages and YouTube videos, radio waves sent by 5G technology are causing small changes in people's bodies that make them succumb to the virus. In the United States, one person died after selfmedicating with chloroquine, which was promoted online as a miracle cure for coronavirus despite its unproven efficacy, and Dr. Anthony S. Fauci, Chief of the U.S. National Institute of Allergy and Infectious Diseases, was assigned more security this month after unsubstantiated theories spread that he was part of a secret chamber working to undermine President Trump.

Retrieved from: https://www.notiulti.com/como-una-teoria-de-la-conspiracion-del-coronavirus-5g-provocoincendios-y-acoso-en-gran-bretana/

5. A characteristic case that drew the attention of public opinion is that of Sweden, which sparked a debate due to the unique strategy of the European country of not confining its population during the pandemic, as it was one of the few countries in Europe that chose not to impose restrictions on its population to prevent the virus from spreading, the problem is that too many people have died. Sweden, a country with 10 million inhabitants, is compared to a smaller number of deaths that the virus has caused in its neighboring countries, Denmark, Norway and Finland, with a total of 15 million inhabitants, which imposed lockdown on their populations. The Swedish government called for civility, offered public health advice but has not imposed restrictions on movement. (It did not even recommend the use of face masks) Contrary to the rest of Europe, even its Scandinavian neighbors. However, the numbers of infections and deaths questioned whether the decision of Stefan Löfven's government had been the right one. The COVID-19 mortality rate is nine times higher than in Finland, almost five times higher than in Norway and more than twice as high as in Denmark. Infections in Sweden at the end of April approached 15,000, deaths exceeded 1,400. Deaths per 100,000 inhabitants in Denmark were 6, in Norway 3.4, and in Finland 1.78. When you think about Sweden, Norway, Finland or Denmark, you think about homogeneous societies with similar behaviors. But in view of the current crisis, Sweden has separated itself from its neighbors. While the rest of the countries have assumed a more protective profile against the disease, Sweden has opted to keep its economy on its feet and respect individual freedom. Social democrats choose economic and individual freedom against the coronavirus. The Swedish former state epidemiologist, Annika Linde, stated that it was a mistake not to close the Swedish country in the face of the Covid-19 pandemic. She stated that tighter restrictions should have been established in the early stages to control the coronavirus. The former official was responsible for overseeing Sweden's response to swine flu and SARS as a state epidemiologist from 2005 to 2013. She subsequently supported the work of her successor, Anders Tegnell, who is fighting the health emergency, however, she rectified and accepted that she should not have relied on "herd immunity". See: https://www.eleconomista.es/ videos/noticias/10494630/04/20/El-modelo-de-Suecia-contra-el-coronavirus-fracasa-el-numero-de-muertes -cuadriplica-la-de-sus-vecinos-escandinavos.html. Also see: https://www.bbc.com/mundo/noticiasinternacional-52690735; https://www.eleconomista.es/videos/noticias/10494630/04/20/El-modelo-de-

Suecia-contra-el-coronavirus-fracasa-el-numero-de-muertes-cuadriplica-la-de-sus-vecinos-

escandinavos.html;https://www.contrareplica.mx/nota-No-cerrar-Suecia-por-Covid-19-fue-un-errorAnnika-Linde202026532

6. Researchers from at least five countries, including Brazil, detected the presence of the new coronavirus in sewage samples collected weeks or months before the first officially recorded case in the Chinese city of Wuhan, considered to be the origin of the current pandemic. But how do these findings of virus in stool affect what we know about SARS-CoV-2? The scientists point to three main thrusts: 1) Monitoring: detection in sewage can serve as a broad and inexpensive tool to monitor the progress of Covid-19. There are at least 15 countries where this strategy has been taken or is being studied. Potential health risk: the presence of the genetic material of the virus in stool indicates that sewage may be considered a route of infection. 2) Pandemic origin: the virus may have been circulating much earlier than indicated in the official timeline. Regarding the third point, the study that gained the most attention was led by researchers at the University of Barcelona, according to which there was presence of the new coronavirus in frozen samples, collected in Spain, since January 15, 2020 (41 days before the first official notification of an infection in the country) and since March 12, 2019 (nine months before the first case reported in China). But how could a virus with the capacity to cause a pandemic have circulated without drawing attention or creating a burst of cases, as happened in Wuhan? Experts quote at least five hypotheses. The first one is that patients may have received incorrect or incomplete diagnoses related to respiratory illnesses, something that would have contributed to 
the initial spread of the disease; the second is that the virus had not spread strongly enough to cause an outbreak. The third and fourth pose problems in the analysis: a) a possible sample contamination or a false positive result, due to genetic similarity with other respiratory viruses or b) failures in the test kit. Finally, there are those who speak of a virus waiting to be activated. Tom Jefferson, an epidemiologist linked to Oxford University's Evidence-Based Medicine Center, told the British newspaper The Telegraph that there is a growing body of evidence that SARS-CoV-2 was widespread before it emerged in Asia. "Perhaps we are seeing a latent virus that has been activated by environmental conditions." In the opinion of Fernando Spilki, president of the Brazilian Society for Virology, it is necessary to wait for more studies on the subject before drawing conclusions regarding the incidence of the virus months before the known origin of the pandemic. In other words, all these results should be evaluated with caution. The characteristic of SARS-CoV-2 of generating high-severity cases with relatively high lethality in the population makes it unlikely that this virus would circulate in a region with no evidence of clinical cases. Retrieved from https://www.msn.com/es$\mathrm{mx} /$ noticias/mundo/cómo-el-hallazgo-de-rastros-del-coronavirus-en-aguas-residuales-de-5-países-antesdel-brote-en-china-aumenta-el-misterio-sobre-el-origen-del-virus/ar-BB16zrqa?ocid=spartan-dhp-feeds

7. Cfr. Provided by However, "Chinese virologist Li-Meng Yan, who fled to the U.S. in April, claims her country lied about COVID-19" https://www.msn.com/es-mx/noticias/mundo/viróloga-china-li-meng-yanquien-huyó-a-eu-en-abril-asegura-que-su-país-mintió-sobre-la-covid-19/ar-BB16Ed5w?ocid=spartan-dhpfeeds July 12, 2020.

8. European Centre for Disease Prevention and Control An agency of the European Union. Retrieved from: https://www.ecdc.europa.eu/en/geographical-distribution-2019-ncov-cases 12/07/2020

9. UN News. https://news.un.org/es/story/2021/05/1492332

10. Joel Achenbach, Karin Brulliard and Ariana Eunjung Cha: "The ultimate Covid-19 mystery: why does it forgive some people and kill others?" https://www.washingtonpost.com/es/tablet/2020/06/22/el-misteriodefinitivo-del-covid-19-por-que-perdona-algunos-y-mata-

otros/?utm_campaign=wp_post_opinion\&utm_medium $=$ email\&utm_source=newsletter\&wpisrc $=$ nl_postop inion

11. https://www.infobae.com/america/mundo/2020/06/25/como-nos-contagiamos-coronavirus-entre-losexpertos-hay-cada-vez-mas-consensos/ June 25, 2020

12. See, Jesús Ruiz Mantilla, "Javier Solana: 'In today's world we need cooperation, but we get confrontation", in Este País, May 30, 2020,

13. https://www.lapoliticaonline.com.mx/nota/129686-china-eleva-la-tension-con-la-casa-blanca-alguien-lespidio-explicaciones-por-el-sida/

14. https://www.excelsior.com.mx/global/china-advierte-de-una-nueva-guerra-fria-con-eu/1383882

15. Fernando Vallespín, "The great losers in this crisis are the "strong men", the populist macho men, and all those who are fighting against the virus as a warlike confrontation".

https:/elpais.com/elpais/2020/04/18/opinion/1587223524_192108.html?ssm=TW_CC, April 18, 2020.

16. Martha Fraile, "Women's leadership in the current crisis." El Pais https://elpais.com/elpais/2020/04/16/ opinion/1587023507_604396.html Accessed April 16, 2020

17. Fran Ruiz, https://www.cronica.com.mx/notas-la_pandemia_pasa_factura_a_los_mandatarios_parte_ii_los_ ganadores-1156232-2020

18. Fran Ruiz https://www.cronica.com.mx/notas-la_pandemia_pasa_factura_a_los_mandatarios_parte_i_los_ perdedores-1156144-2020

19. The Group of Associated Economists (GEA by its acronym in Spanish) and Applied Social Investigations S.C (ISA by its acronym In Spanish). published on July 2, 2020 the results of their study: Mexico: Governance in times of the Fourth Transformation. Political Scenarios, which analyzes citizens' expectations regarding the government of Andrés Manuel López Obrador. Some of the results are as follows: 1) Approval of President Andrés Manuel López Obrador's management decreased nine percentage points with respect to March and disapproval increased twelve: $39 \%$ vs. $58 \%$. 2) The drop is mainly caused by the negative impact the economic crisis is having on families, 3 ) The Covid-19 pandemic has had a very strong negative effect on the economy of families and President Lopez Obrador's handling of the pandemic is also more rejected (56\%) than approved (44\%), 4) The disapproval of the security and corruption politics grew, 5) Two thirds of the citizens think that the country is going in the wrong direction, 6) Society is deeply polarized around López Obrador's government.

20. Juan Omar Fierro, "The risks of official arrogance", Mexico, Proceso, No. 2263, March 15, 2020, p. 6.

21. Claudia Villegas, "We are in the midst of turbulence", Mexico, Proceso, No. 2263, March 15, 2020, p. 16. 
22. Arturo Rodríguez García, "Calm excess in the face of the emergency", Mexico, Proceso No. 2264, March 22,2020, p. 7

23. Juan Omar Fierro, "Deficit of 17 thousand beds", Mexico, Proceso, No. 2264, March 22, 2020, p. 8

24. In order to guarantee healthcare for the beneficiaries of public security institutions, the Ministry of Health signed a collaboration agreement whereby the National Association of Private Hospitals and the Mexican Hospital Consortium made available to the federal government half of the beds in the 146 hospitals that belong to these groups. Thus, between April 23 and May 23, these beds will be used to provide second-level healthcare services for patients referred by public institutions for childbirths, cesarean sections, appendix diseases, complicated hernias, and gastric ulcers, among other non-serious conditions. https://www.gob.mx/issste/articulos/convenio-con-hospitales-privados

Juan Carlos Cruz Vargas, "The pandemic is raging against informal commerce” Mexico, Proceso, No. 2264, pp. 14-17

26. Rafael Croda and Rosalía Vergara, "No work and no money", Mexico, Proceso, No. 2265, March 29, 2020, p. 8

27. https://palabrasclaras.mx/economia/12-apoyos-del-gobierno-que-debes-tener-en-cuenta-en-tiempos-deCovid-19/

28. Juan Carlos Cruz Vargas, "No governmental plan for the contingency: Salazar Lomelín", Mexico, Proceso, No. 2265, March 29, 2020, p. 12

29. Claudia Villegas, "A war economy is imposed", Mexico, Proceso, No. 2265, March 29, 2020, p. 16

30. Neldy San Martín, "The 'economic storm' hits the television duopoly...the pandemic gives it a breathing space”, Mexico, Proceso, No. 2265, March 29, 2020, p. 25

31. https://www.gob.mx/presidencia/documentos/algunas-lecciones-de-la-pandemia-covid-19

32. Presidency of the Republic, The new economic politics in the times of the coronavirus, May 15, 2020

33. See DOF DECREE establishing the austerity measures to be observed by the agencies and entities of the Federal Public Administration under the criteria indicated therein. 23-04-2020

34. Presidency of the Republic, The new economic politics in the times of the coronavirus, Op. Cit.

35. Mateos Vega, Mónica, "Neoliberal politics are the cause of multiple epidemics: Historian". La Jornada, October 4, 2020, 7a.

36. Enciso, Angélica, "Mexico has reduced its life expectancy without going through a war process". La Jornada, September 25, 2020, p. 32.

37. Cruz Martínez, Ángel, "Strategy against the epidemic, under constant sabotage: López-Gatell", La Jornada, September 14, 2020, p. 2.

38. Reyes Terán, Gustavo, "How was hospital collapse avoided in Mexico?" La Jornada, September 4, 2020, p. 31.

39. Cruz Martínez, Ángeles “Covid determines the government's year”, La Jornada, December 1, 2020, p. 5.

40. Laurell, Asa Cristina. “Towards a single health system?”, La Jornada, September 10, 2020, 3a.

41. Laurell, Asa Cristina, "What is the approach to dealing with the pandemic?" La Jornada, October 8, 2020, $3 a$.

42. Cruz Lera, Estefanía "The Covid-19 pandemic and the dilemmas of the health commons in North America", Globalítika, 2020, p. 8.

43. Laurell, Asa Cristina, "Excess mortality and social determinants". La Jornada, November 12, 3a.

44. Azam Ahmed, "Mexico's president refuses to spend in big way to cushion coronavirus impact" https://www.nytimes.com/es/2020/06/08/espanol/america-latina/mexico-amlo-deuda-coronavirus.html Accessed June 8, 2020.

45. https://www.laoctava.com/internacional/universidad-de-washington-contradice-pronostico-de-lopez-gatellmexico-tendra-mas-de-50-mil-muertes-por-coronavirus. Accessed on June 9, 2020

46. https://www.reforma.com/proyectan-132-mil-muertes-enmexico/ar1953067?utm_source=bcm_nl_coronavirus_reforma\&utm_medium=email\&utm_campaign=nl_c oronavirus_reforma_20200528. Accessed on May 28, 2020

47. Julio Hernández López, https://www.washingtonpost.com/es/post-opinion/2020/05/11/la-verdaderadiscusion-detras-de-las-cifras-de-covid-19-en-mexico/?itid=1k_inline_manual_81 Accessed on May 11, 2020

48. Op Cit.

49. Especiales 14. Learning to live with coronavirus. An interview with Dr. Hugo Lopez-Gattel https://www.youtube.com/watch?v=U_UMpH-egYs July 6, 2020. 
50. We refer to the study 'Covid-19 mortality in Mexico. Preliminary notes for a sociodemographic profile', developed by Héctor Hernández Bringas, $\mathrm{PhD}$ in Social Sciences, from the Regional Multidisciplinary Research Center (CRIM by its Spanish acronym) of the UNAM. Based on statistics from the Ministry of Health (SSA) and death certificates issued up to May 27, 70\% of those who died from Covid-19 are men, i.e. 2.1 men per woman. Seventy-one percent of the deceased men were between the ages of 40 and 69 . Among men, 9 percent were under 40 years old and 20 percent were 70 years old or older. Among women, a similar trend is found: 65 percent of deaths occur between the ages of 40 and $69 ; 27$ percent were 70 years old or older and 9 percent were under 40 years old according to the study. As of May 27, the country's mortality rate was 7.07 per 100,000 inhabitants. Retrieved from:https://www.excelsior.com.mx/nacional/71-de-losmexicanos-muertos-por-covid-19-con-escolaridad-de-primaria-o-inferior/1393033

51. Mateos Vega, Mónica (2020 b, September 1). When an epidemic ends, collective amnesia occurs, warns the historian. La Jornada, 3a.

52. Mateos Vega, Mónica, "Pandemics generate resilient or incredulous societies: Experts," La Jornada, September 17, 2020, 5a.

53. Mateos Vega, Mónica, "Neoliberal politics are the cause of multiple epidemics: Historian". La Jornada, October 4, 2020, 7a.

54. McNeil Jr., D. G. "The big pandemic mystery: how lethal is the coronavirus?" The New York Times, July 6, 2020, p 6.

55. Mateos Vega, Mónica, "History shows that health professionals are only recognized in rhetoric: Specialist". La Jornada, September 18, 2020, 3a.

56. Donald F. Kettl, "States Divided: The Implications of American Federalism for Covid-19" https://onlinelibrary.wiley.com/doi/full/10.1111/puar.13243?af=R, May 22, 2020

57. Manuel Alcántara, "And the streets were emptied" https:/latinoamerica21.com/y-las-calles-se-vaciaron. April 22, 2020.

58. Manuel Alcántara "Points for a political agenda in Latin America". Retrieved from: https://www.politicaexterior.com/puntos-para-una-agenda-politica-en-america-latina/ June 3, 2020

59. Such as the manifest signed by Thomas Piketti, James Galbraith, Benjamin Sachs, Dani Rodrik, Isabelle Ferreras, Julie Battilana, Dominique Méda and others (which some may find populist) entitled: "Work. Democratize. De-commercialize. Decontaminate, that is, democratize the company and de-commercialize work to ensure that the community guarantees useful employment for all. At this crucial moment, when we are facing at the same time a risk of pandemic and a risk of climate collapse, these two strategic transformations would allow us not only to guarantee the dignity of each person, but also to act collectively to decontaminate and save the planet. published in Le Monde, Die Zeit, Boston Globe, Le Soir, De Morgen and The Guardian. Retrieved from: https://www.lavanguardia.com/economia/20200515/481152970981/ manifiesto-democratizing-work-trabajo-democratizar-desmercantilizar-descontaminar.html? fbclid= IwAR2I1ZBOuo6rT0iGJVSvuxr1PnoPvVd3PdB8t0RY8WPuRrvXuXWJcGyday4 16-05-2020

60. https://www.elfinanciero.com.mx/salud/es-muy-poco-probable-que-en-la-situacion-actual-se-puedaerradicar-el-covid-19-oms 10-07-2020 